\title{
The effective points of view of Hunedoara Energetic Complex
}

\author{
Sorin Mihai Radu ${ }^{1, *}$, Nicolae Iliaş ${ }^{1}$, Eduard Mija ${ }^{2}$ \\ 1 University of Petroşani, 20 Universităţii Street, Petroşani - 332006, Romania \\ ${ }^{2}$ Hunedoara Energetic Complex, Petrosani - 336250, Romania \\ *E-mail address: a86iorgulescu@yahoo.com
}

\begin{abstract}
The future of coal mining in Jiu Valley is acutely conditioned by a multitude of factors, arising from the interference of force lines of different decision centres, the effects of which - often cumulative or even antagonistic - may lead to irreparable consequences. The failure to take into account the totality of all the economic, social-geographic, technogenic and anthropogenic aspects have not allowed until now the outline of realistic and viable scenarios which may cut the Gordian knot of the multilevel challenge which this socio-industrial complex faces, scenarios which shall be the basis of a coherent and consequent strategy, challenges which unsolved may produce irreversible and dramatic effects for the future of the area as well as that of the national economy. The paper intend to offer - at least as a methodological approach - an assessment based on the scenarios of benefits and losses which the national economy may record by ignoring or not taking into a fair account of the proportion of the role of this industrial complex for Romania's energetic future.
\end{abstract}

Keywords: Scenarios; energetic; coal; Jiu Valley

\section{INTRODUCTION}

An analysis, even superficial, of the decision to appoint the Hunedoara Energetic Complex (HEC) in November 2012, proves that it was taken considering criteria related mainly on the emphasised interdependence between the energetic resource supplier (the internal producer of energetic coal, the former NCC of Petroşani, divided in 2001 in two independent entities, namely NCS and NCCMJV), and the two central heating and power producers existent in the area, respectively Mintia and Paroşeni Central Heating Plants, and secondly on social criteria related to the quasi mono-industrial character of the area.

\section{TECHNICO-ECONOMICAL CONSIDERATIONS}

The two central heating plants included in the structure are different from several points of view:

- $\quad$ The theoretic designed and installed capacity of Mintia Central Heating Plant is of 1285

MWh, comprised in 6 groups ( 5 210MWh groups, out of which one was put out of 
operation in 2012, and a 235MWh rehabilitated one), but there are also a set of problems which are not to be neglected, namely:

○ The removal of operation of two groups as they do not meed the European environmental standards;

- Total removal of a group which was proposed for cassation;

- Investments for the rehabilitation of the technology of the desulphurisation and dense slam installations for the two remaining groups which are estimated to an approximate amount of 203.5 million Euros.

- Paroseni Central Heating Plant disposes of a single rehabilitated group (respectively Gorup IV), which has a capacity of $150 \mathrm{MWh}$, the commercial operation of which began in 2007. Environmental conditions are partially met as the investments for the rehabilitation of the desulphurisation and dense slam installations having begun in 2013, with a period for finalisation of 31 months from the beginning of the investment.

As it has already been mentioned, the main common denominator of the two central heating plants is represented by the fuel they use, respectively energetic coal extracted from Jiu Valley coal basin. Theoretically correct, the integration of viable mines (belonging to the $\mathrm{NCSH}$, later on having become the mining division of the $\mathrm{ECH}$ ) within this complex was carried out without a thorough economical assessment and without being based on a coherent restructuring and technologic rehabilitation programme.

The need of such a programme is proven by the extraction costs of coal which vary from 74 lei/Gcal, in the case of Vulcan mine, and respectively 157 lei/Gcal, in the case of Lupeni mine, with an average therefore at the level of the mining division of 104 lei/Gcal.

The viability barometer of the entire complex revolves around the selling price of energy on a competing market, an average price for September 2013 of 171.89 lei/MWh (PZU) and of 195.82 lei/MWh on PCCB. As a basis for comparison, the production cost of one MWh is situated around 270 lei considering that coal was bought with 69 lei/Gcal.

Considering that almost $70 \%$ of the cost of a MWh is represented by coal, it results therefore that the production cost is 540 lei/MWh.

Therefore, it is required for the Hunedoara Energetic Complex to solve the problems which weren't dealt with since 1990 until present times.

\section{POSSIBLE SCENARIOS REGARDING THE FUTURE OF THE HUNEDOARA ENERGETIC COMPLEX}

Considering the above presented facts, the following scenarios regarding the future of Hunedoara Energetic Complex may be formulated:
A. Scenario no. 1 - very pessimistic
a. Bankruptcy,
b. Failure to go private,
c. Bankruptcy of the Hunedoara Energetic Complex,
d. Laying off and sending into unemployment all the employees of the complex.

B. Scenario no. 2 - pessimistic moderated
a. Bankruptcy, 
b. Externalisation of the actual viable components, namely Paroseni Power Plant and a maximum of 2 mines,

c. Closing the unsustainable activities, namely Mintia Power Plant and the other mines,

d. Laying off and sending into unemployment of $2 / 3$ of the employees of the complex.

\section{Scenario no. 3 - pessimistic moderated}

a. Bankruptcy,

b. Externalisation of viable energetic groups (Group IV Paroşeni and groups 3 and 4 Mintia),

c. Closing completely the mining activity,

d. The withdrawal and capitalisation of the remaining groups at Mintia, coal import and partial acquisition of the NCCM of Jiu Valley.

\section{Scenario no. 4 - optimistic}

a. Avoiding bankruptcy

b. Investment implementation,

c. Tripling the mining productivity,

d. Situating within the costs,

e. Survival and consolidation of the complex

It is therefore considered that these scenarios require thorough technical and economical fundaments, in the shortest period of time possible in order to be considered as a base for future political and administrative decisions.

If Scenario no. 1 is taken into consideration, the scenario in which the disappearance of the coal mining industry of Hunedoara County it is rendered effective, then the socialeconomical effects shall occur immediately as well as on a long term. These statements are supported by a series of data brought forward herein after.

The menace of the coal mining industry of Hunedoara County may be measured in immediate effects as well as in long term ones. It is although considered that the two companies created at the end of 2012, which divide the mines in sustainable and unsustainable ones, need to represent only a step on the road to reinvigorate the activities of the Jiu Valley coal basin.

On one hand, the time limit of the National Company for the Closing of Mines of Jiu Valley, which comprises Petrila, Paroseni and Uricani mines, is the year 2018. In numbers, though, this company means goods and services costs of 71,995 thousand lei, fees and taxes and other assimilated transfers of 6,655 thousand lei and other operational expenses and staff costs of 24,200 thousand lei. Wages, bonuses and other staff costs including mandate costs of 126,161 thousand lei are also added, together with social protection and insurance costs of 39,609 thousand lei. Investment costs were estimated to be 6,585 thousand lei. By the end of 2013 the company foresaw an effective of 1940 people and wages including bonuses of 3,971 lei.

On the other hand, the National Society of Coal (appointed following an absorption fusion process within the Energetic Complex of Hunedoara during 2013) comprises Lonea, Vulcan, Livezeni and Lupeni mines as well as the Coal Preparation Unit and Mine Saving Station. In numbers, this company means goods and services costs of 144,432 thousand lei, fees, taxes and other assimilated transfers of 25,798 thousand lei and other operational costs of 32,810 thousand lei. Wages, bonuses and other staff costs including mandate expenses of 231,364 thousand lei are also added, together with social protection and insurances costs of 
83,430 thousand lei and financial costs of 12 thousand lei. Investment costs were estimated to reach 30,829 thousand lei. By the end of 2013 the company foresaw an effective of 5,014 people and wages including bonuses of 3,749 lei.

The staff number of the two companies represents $6.22 \%$ of the total number recorded at the end of October 2013 in the entire County, and approximately $30 \%$ in Jiu Valley (approximate number, estimated due to the lack of statistical data) respectively $(0.15 \%$ on a national scale) while the income of the personnel of the two units represented an important influence on average gross income of 1,888 lei recorded in the county by the end of the same month.

The contributions for the employees for the consolidated State Budget, representing health, unemployment, social state contributions, taxes amount yearly to approximately 105,000 thousand lei, while the main destination for the expenses of the net income are food and beverages which amount to approximately 51,518 thousand lei, the purchase of non-food merchandise being estimated around 46,795 thousand lei, services 38,209 thousand lei, income taxes, contributions and other fees 36,707 thousand lei.

The National Society of Coal has set to have total revenues of 268,620 thousand lei for 2013 while The National Company for the Closing of Mines total revenues of 517,846 thousand lei.

After the National Society of Coal was appointed to be a composing part of Hunedoara Energetic Complex beginning with July 2013 the budget of the new company was the following:

- Expenses for goods and services 828,557 thousand lei,

- Fees, taxes and other assimilated transfers of 14,505 thousand lei,

- Other operational costs of 137,124 thousand lei;

- Wages, bonuses and other staff expenses, including mandate costs 193,401 thousand lei

- Social protection and insurances 60,976 thousand lei.

- Financial expenses 55,455 thousand lei;

- The investments expenses were estimated to reach the amount of 228,766 thousand lei.

By the end of 2013 the company forecasted an effective of 6,829 people and wages including bonuses of 3,845 lei. The losses suffered by the State concerning the future complex may be estimated if the above stated scenarios are taken into consideration, as follows:

\section{A. Scenario no. 1 - very pessimistic:}

Romania, as a consequence of the cease of coal mining, directly loses every year approximately 51.91 million Euros from contributions to the State Budget and the local budgets to which unemployment benefits are added, which need to be paid to former or potential future employees. The unemployment rate of the county is to increase with over $7.8 \%$. The turn-over of partner companies and other connected industries is directly affected and may drop with approximately 235.97 million Euros every year, while the losses from the contribution of the employees to the turn-over / companies' revenues / public institutions which produce or sell food, non-food merchandise, services, contributions, fees, taxes, etc. would amount to 46.16 million Euros every year. 


\section{B. Scenario no. 2 - pessimistic moderated}

Romania, as a consequence of the decrease of the coal mining activity, directly loses every year approximately 42.27 million Euros from contributions to the State Budget and the local budgets to which unemployment benefits are added, which need to be paid to former or potential future employees. The unemployment rate of the county is to increase with over 4.48 $\%$. The turn-over of partner companies and other connected industries is directly affected and may drop with approximately 39.39 million Euros every year, every year, while the losses from the contribution of the employees to the turn-over / companies' revenues / public institutions which produce or sell food, non-food merchandise, services, contributions, fees, taxes, etc. would amount to 33.42 million Euros every year.

\section{Scenario no. 3 - pessimistic moderates}

Romania, as a consequence of closing-down the coal mining activity, directly loses every year approximately 62.36 million Euros from contributions to the State Budget and the local budgets to which unemployment benefits are added, which need to be paid to former or potential future employees.

The unemployment rate of the county is to increase with over $6.22 \%$. The turn-over of partner companies and other connected industries is directly affected and may drop with approximately 60.76 million Euros every year, while the losses from the contribution of the employees to the turn-over / companies' revenues / public institutions which produce or sell food, non-food merchandise, services, contributions, fees, taxes, etc. would amount to 27.81 million Euro every year.

\section{Scenario no. 4 - optimistic}

There are no losses, the State revenue would amount to approximately 51.91 million Euros million Euros from contributions to the State Budget and the local budgets, the contribution of the turn-over of partner economic entities and activities connected to coal mining, would amount to approximately 235.97 million Euros per year, while the contribution of employees for the turn-over / companies' revenue / public institutions which produce and / or sell food merchandise, services, contributions, fees, taxes, etc. would amount to 46.16 million Euros every year.

As a synthesis, the losses / revenues for the 4 scenarios are compared and presented in absolute values in Figure, while Figures bring forward their losses for scenarios no. 1, 2, and 3 , and respectively the revenue for scenario no. 4 in percentages per category.

\section{SWOT ANALYSIS FOR THE CAPITALISATION OF COAL}

\section{Strengths:}

The existence of an industrial reserve of approximately 260 million tons, in the seven active perimeters found within the concession of the two mining companies, out of which approximately 94 million tons is considered to be exploitable with the actual mines network. This reserve may ensure the energy production for the following 100 years;

$\checkmark \quad$ The surface and underground existent coal mining and rail hauling and transport infrastructure to its beneficiaries;

$\checkmark \quad$ Concentrating the mines in a relatively small area; 
$\checkmark \quad$ Reduced distance between the mines and its beneficiaries;

$\checkmark \quad$ The existence of qualified and trained personnel for the mining acticity, meaning tradition and professional experience on all levels;

$\checkmark \quad$ The demand for trained staff is covered considering the training quality and the number of people;

$\checkmark \quad$ The essential contribution to the safety of national energy if there is a crisis of other resources;

$\checkmark \quad$ The parameters of the products developed with the help of present mining and preparation technologies compatible with the coal burning installations belonging to the beneficiaries;

$\checkmark \quad$ Coal preparation installations may realise products with a high energetic content;

$\checkmark \quad$ Romanian Central Heating Power Plants are designed to operate with solid fuels with the quality parameters of Jiu Valley coal, which creates a certain dependence on mines;

$\checkmark \quad$ The required coal quantities may be ensured for the beneficiaries, for the right quality according the their demand and for a price much smaller than the price of imported coal;

$\checkmark \quad$ Strategic coal reserves may play an anti-speculative role, fact which the European Union did not fail to highlight considering that the Union in incapable of negociaitng the price for energetic resources and cannot put pressure on these markets;

$\checkmark \quad$ The high proportion of haulage and transportation costs comprised in the price of coal (approximately $50 \%$ of the price of coal imported from Europe and Japan), fact pleading for the use of national and local coal.

\section{Weaknesses:}

$\checkmark \quad$ The tough geological-mining conditions, such as: high mining depth, complicated tectonics, the presence of methane, and others;

$\checkmark \quad$ Low caloric power and the high content of sulphur of the Jiu Valley coal compared to the offer of external markets (Vlăduţescu, 2013);

$\checkmark \quad$ Reduced possibilities to significantly increase the quality of production with the actual operating technology;

$\checkmark \quad$ The reduced mechanisation degree of the mining activity, the moral and physical wear of mining machineries and equipments (coal mining mechanised complexes, the longwall and face cutter, drilling equipments, underground hauling equipments, underground waters evacuation equipments, air shaft installations, extraction installations, automation and dispatch equipments) (Siminică \& Traistaru, 2013);

$\checkmark \quad$ The lack of modern technologies which can adapt to the conditions of the ore, the insufficient number of modern coal cutting equipment, roof supports, hole drilling, rock cutting for the preparation and mine opening works and well drilling;

$\checkmark \quad$ Difficulties with the selective coal mining;

$\checkmark \quad$ Increased production costs (Dima, 2013);

$\checkmark \quad$ Labour productivity on a mine level, under 300 t/person/year, situated a lot under the world level;

$\checkmark \quad$ Increased mining accidents risk favoured also by the lack of monitoring means of the coal face space;

$\checkmark \quad$ Failure to carry out the investment works on time, investments required for the operation of new production capacities of most of the mines; 
$\checkmark \quad$ Failure to carry out in time the geological researches for the identification of which ore presents itself with the best mining conditions with direct implications on the development of the viable production capacities (Bajdor \& Grabara, 2014; Vlăduţescu, 2014);

$\checkmark \quad$ Unused industrial constructions inside the perimeter of the mines, due to having narrowed down the mining activities and failure to use them for other purposes.

\section{Opportunities:}

$\checkmark \quad$ The increase demand of primary energy sources;

$\checkmark \quad$ A relatively stable outlet market;

$\checkmark \quad$ Possibilities to increase the revenues by improving the quality of yhe producs;

$\checkmark \quad$ The increase of the proportion of coal within the heating and power production on an international level;

$\checkmark \quad$ Still increased energy production costs from regenerating sources;

$\checkmark \quad$ The appointment of Hunedoara Energetic Complex;

$\checkmark \quad$ Maintaining an adequate mining infrastructure for coal mining in order for the continuity of production to be ensured for a long period of time;

$\checkmark \quad$ The possibility to implement methane holding installation from coal and methane emissions of the mined ore;

$\checkmark \quad$ Improving the quality of sold coal with small investments for technologic rehabilitation of the sorting equipment of each mine;

\section{Threats:}

$\checkmark \quad$ The regression of the international economic crisis;

$\checkmark \quad$ The vulnerability of coal mining considering the geological-mining characteristics and conditions (Traistaru \& Avram, 2014; Dima \& Vlăduţescu, 2012);

$\checkmark \quad$ The increase of production costs generated by the compulsory additional labour safety and health, and environmental conditions;

$\checkmark \quad$ Increased social vulnerability due to the mono-industrial character of the area, and the regression of the economical situation (Powell, 2014);

$\checkmark \quad$ The reduction of the number of jobs in Jiu Valley due to the reduction of the mining activity in Jiu Valley as there is a lack of a real economic alternative (Smarandache \& Vlăduţescu, 2014);

$\checkmark \quad$ The dependence of the coal production on the operation of the two Central Heating Power Plants;

$\checkmark \quad$ The lack of a controlled price of coal close to the production cost;

$\checkmark \quad$ The lack of funds for an extensive development of mining;

$\checkmark$ Reduced chances to ensure the investments for rendering the mines viable considering the present organisational conditions;

\section{TECHNICAL ECONOMICAL PROPOSALS FOR THE CAPITALISATION OF COAL}

The propositions are based on the pure truth verified in practice, namely "If there is no investment any activity inevitably meant to fail".

1. Buying coal from the NCCM JV and from the mines which have the smallest price; 
2. Realising an investment program for new technologies and machineries which will determine the production cost of coal;

3. Investing into a new $200 \mathrm{MWh}$ energetic block with overcritical parameters for Paroseni Central Heating Power Plant;

4. Realising a series of investments for the rehabilitation of the technologies for the desulphurisation and dense slam of groups 3 and 4 at Mintia Central Heating Power Plant;

5. Implementing a series of projects for methane holding installations coming from coal and the emissions of methane from the mined coal;

6. Investments for additional installations for the desulphurisation and dense slam installations;

7. The removal and periodic invalidation of groups 2, 5 and 6 from Mintia;

8. The realisation of a new $400 \mathrm{MWh}$ group at Mintia Central Heating Power Plant, a gas turbines combined cycle;

9. The realisation of a central deposit in Jiu Valley for the homogeneity and delivery of coal to the beneficiary.

\section{CONCLUSIONS}

In order to avoid bankruptcy it is extremely important to render the mines viable, to capitalise methane which accompanies the coal deposit of Jiu Valley as well as perform a thorough waste management. It may therefore be contributed to the assurance of energetic independence of the area and a series of other problems related to the geographical area of the future HEC may be solved. HEC is found in a delicate situation generated by the difficulties with which the National Energetic System is currently facing, namely a surplus of energy created by regenerative and hydro sources considering that Romanian energetic consumption has dramatically decreased as well as the Agreements signed by the Government with external creditors such as the IMF - WB - EC regarding the future Hunedoara Energetic Complex make it private or in case of failure, bankruptcy.

It is appreciated that the action of going private is going to fail, and bankruptcy was agreed upon through a letter of intent signed with the IMF - WB - CE, action which shall be finalised with the bankruptcy of viable mines as well as Paroseni Central Heating Power Plant.

If going private shall fail, in order not to reach in the situation to decide judicial management, moment from which it is practically impossible to avoid bankruptcy, the following actions are proposed:

a) The development of a project by the specialists of the two central heating power plants, the viable and non-viable mines, of the University of Petrosani, and of the Local Administration, for the identification of consumers of thermal and electric energy supplied by Paroseni Central Heating Power Plants, considering that the price of natural gases is continuously increases. The main measures which were proposed for this strategic document are the following:

- $\quad$ The development of the heating system within the entire Jiu Valley through works for the rehabilitation of the main pipe and its extension to Uricani and Petrila;

- The rehabilitation of the distribution network for the thermal agent and the existent district heating substations and the construction of new networks in Uricani and Petrila; 
- $\quad$ The supply of energy from Paroseni Central Heating Power Plant to all the local administrations, population and economic entities with competing prices;

- Carrying out collateral investments which will use the existent energetic infrastructure;

- The purchase of an ecologic waste burning installation and using the thermal agent in the heating network.

b) Rendering the mines of Jiu Valley viable. It is appreciated that the demand of coal, corresponding to the energetic consumption of Jiu Valley, does not exceed approximately 1.5 million tons per year, if the additional energy produced by burning the waste and the methane collected from the coal deposits are also taken into consideration. This production may be realised with approximately 2,500 - 3,000 employees. Taking into account substantial technical-economical criteria, the mines need to select the deposits which offer the most favourable mining conditions for the application of modern operating technologies.

The capitalisation of the activity in Jiu Valley may be done through the identification of new consumers and the increase of the demand for thermal and electric energy and by carrying out the proposed investments.

\section{References}

[1] I. C. Dima, M. Man (2013). Budgeting and Management Control in Industrial Companies. Saarbrucken: LAP Lambert Academic Publishing.

[2] G. Chiril, N. Iliaş, S. M. Radu, I. Gruneanţu, (2012). Environmental protection and opportunities for harnessing jiu valley's hard coal energetic potential. First International Conference on MOLDAVIAN RISKS - FROM GLOBAL TO LOCAL SCALE 16-19 May 2012, Bacau, Romania.

[3] Andrzej Borowski, International Letters of Social and Humanistic Sciences 14 (2014) 7-17.

[4] Ştefan Vlăduţescu, European Scientific Journal 9(32) (2013).

[5] Mesagerul Energetic. Information Bulletin of CNR-CME 144 (2013).

[6] I. Andras, N. Ilias, D. Barbu, I. Cioara, L. Toma, L. Codreanu (2013). The energetic policy in Romania. Moscow, "Nedelia Gorniaka" International Conference, 2013.

[7] Andrzej Borowski, International Letters of Social and Humanistic Sciences 11 (2014) $1-168$.

[8] Ş. Vlăduţescu, E. M. Ciupercă (2013). Next Flood Level of Communication: Social Networks. Aachen: Shaker Verlag.

[9] I. C. Dima, J. Grabara, P. Pachura Polish Journal of Management Studies 1 (2010).

[10] Decision no. 328/2013 for the approval of the revenues and expenses budget for 2013 of the National Company for the Closing of Mines of Jiu Valley - S.A., found under the authority of the Ministry of Economy.

[11] I. C. Dima, M. Man, Annals of the University of Petroşani, Economics XII (2012).

[12] Andrzej Borowski, International Letters of Social and Humanistic Sciences 3 (2013) 69-74. 
[13] Ştefan Vlăduţescu (2014). Convictive Communication and Persuasive Communication. International.

[14] Marian Siminică, Aurelia Traistaru, International Journal of Education and Research 1(12) 2013.

[15] Decision no. 603/2013 for the approval of the revenues and expenses budget for 2013 of the National Society of Coal - S.A. Petroşani, found under the authority of the Minstry of Economy. Territorial Statistics 2013 - Total expenses of households - The Western Region www.insse.ro

[16] Paula Bajdor, Iwona Grabara, (2014). The Role of Information System Flows in Fulfilling Customers' Individual Orders. Journal.

[17] Aurelia Traistaru, Marioara Avram, International Letters of Social and Humanistic Sciences 13 (2014) 79-88.

[18] Michal Kolcun, Sebastian Kot, Janusz Grabara (2014). Use of elements of semiotic language in tourism marketing. International.

[19] Petre Bosun, Vladimir Modrak, International Letters of Social and Humanistic Sciences 14 (2014) 66-72.

[20] Ştefan Vlăduţescu (2013). What Kind of Communication Is Philosophy. Jokull.

[21] I. C. Dima, M. Man, Studia Universitatis Petru Maior - series OECONOMICA, Fasciculus, anul VI (2012).

[22] Andrzej Borowski, International Letters of Social and Humanistic Sciences 4 (2013) 70-74.

[23] B. M. Dascălu (2014). Echivocul imagologic în Caietele lui Emil Cioran. Studii de Ştiinţă şi Cultură.

[24] I. C. Dima (2013). Industrial Production Management in Flexible Manufacturing Systems. IGI Global USA.

[25] F. Hristea, M. Colhon (2012). Feeding syntactic versus semantic knowledge to a knowledge-lean unsupervised word sense disambiguation algorithm with an underlying Naïve Bayes model. Fundamenta Informaticae.

[26] Ștefan Vlăduțescu (2013). Principle of the Irrepressible Emergence of the Message. Jokull.

[27] Andrzej Borowski, International Letters of Social and Humanistic Sciences 2 (2014) 110-121.

[28] Ştefan Vlăduţescu (2014). Communication on the difficult route of lie. International.

[29] Tomasz Lis, Paula Bajdor (2013). Sales Logistics as a Model Used by Companies Fulfilling Individual Customer's Needs. In: Challenges in Contemporary Management. Monograph. Scientific Editors Anna Lemańska-Majdzik, Piotr Tomski, Sekcja Wydaw. WZ PCzęst, Czestochowa.

[30] I. Iancu, N. Constantinescu, M. Colhon, International Journal of Computers Communications \& Control 4(5) (2010) 525-531.

[31] Florentin Smarandache, Ştefan Vlăduţescu (2014). Communication Neutrosophic Routes. Columbus, OH: Educational Publishing. 
[32] Petre Bosun, Janusz Grabara, International Letters of Social and Humanistic Sciences 14 (2014) 59-65.

[33] Ioan Constantin Dima, Ştefan Vlăduţescu (2012). Persuasion elements used in logistical negotiation: Persuasive logistical negotiation. Saarbrucken: LAP Lambert Academic Publishing.

[34] Janusz Grabara, Michal Kolcun, Sebastian Kot (2014). The Role of Information Systems in Transport Logistics. International.

[35] F. Smarandache, Ş. Vlăduţescu (2014). Neutrosophic Emergences and Incidences in Communication and Information. Saarbrucken: LAP Lambert Academic Publishing.

[36] Andrzej Borowski, International Letters of Social and Humanistic Sciences 6 (2013) 86-90.

[37] Ştefan Vlăduţescu, International Letters of Social and Humanistic Sciences 10(2) (2014) 100-106.

[38] Colhon M. (2013). Automatic Lexical Alignment between Syntactically Weak Related Languages. Application for English and Romanian. In Computational Collective Intelligence. Technologies and Applications (pp. 266-275). Springer Berlin Heidelberg.

[39] Ştefan Vlăduţescu (2014). From Personal and Social Relationships to Social Networks. International.

[40] J. Grabara, M. Kolcun, S. Kot, International Journal of Education and Research 2(2) (2014).

[41] P. Bajdor, I. Grabara, Journal of Studies in Social Sciences 7(2) (2014).

[42] I. Iancu, N. Constantinescu, M. Colhon, International Journal of Computers Communications \& Control 4(5) (2010) 525-531.

[43] Andrzej Borowski, International Letters of Social and Humanistic Sciences 4 (2013) 70-74.

[44] B. M. Dascălu (2006). Germanitatea şi literele române. Bucureşti: Editura Fundaţia Culturală Ideea Europeană.

[45] Petre Bosun, Mirela Teodorescu, Bianca Teodorescu (2014). Corporate Social Responsibility - Collaborating for the Future. International.

[46] Rajesh K. Yadav, International Letters of Social and Humanistic Sciences 10(2) (2014) 84-90.

[47] Sorin Mihai Radu, International Letters of Social and Humanistic Sciences 16 (2014) 184-193.

[48] Ioan Constantin Dima, Ştefan Vlăduţescu (2012). The Environment of Organizational Entities and its Influence on Decisional Communication. International.

[49] Jacek Tittenbrun, International Letters of Social and Humanistic Sciences 9 (2014) 26-48.

[50] Jason L. Powell, International Letters of Social and Humanistic Sciences 17(1) (2014) $1-60$. 
[51] Jason L. Powell, International Letters of Social and Humanistic Sciences 7 (2014) 22-30.

[52] Goran Rajović, Jelisavka Bulatović, International Letters of Social and Humanistic Sciences 15(2) (2014) 125-137.

[53] Ioan Constantin Dima, Janusz Grabara, Vladimir Modrak, International Letters of Social and Humanistic Sciences 15(2) (2014) 148-156.

[54] Nirmal Kumar Betchoo, International Letters of Social and Humanistic Sciences 16(1) (2014) 39-48. 